Article

\title{
Life Cycle Costing in Sustainability Assessment-A Case Study of Remanufactured Alternators
}

\author{
Erwin M. Schau *, Marzia Traverso, Annekatrin Lehmann and Matthias Finkbeiner \\ Department of Environmental Technology, Technische Universität Berlin, Office Z1, \\ Strasse des 17. Juni 135, Berlin D-10623, Germany; E-Mails: marzia.traverso@tu-berlin.de (M.T.); \\ annekatrin.lehmann@campus.tu-berlin.de (A.L.); matthias.finkbeiner@tu-berlin.de (M.F.) \\ * Author to whom correspondence should be addressed; E-Mail: erwin.schau@tu-berlin.de; \\ Tel.: +49-30-314-28517; Fax: +49-30-314-21720.
}

Received: 19 October 2011; in revised form: 8 November 2011 / Accepted: 9 November 2011 / Published: 18 November 2011

\begin{abstract}
Sustainability is on the international agenda, and is a driver for industry in international competition. Sustainability encompasses the three pillars: environment, society and economy. To prevent shifting of burden, the whole life cycle needs to be taken into account. For the environmental dimension of sustainability, life cycle assessment (LCA) has been practiced for a while and is a standardized method. A life cycle approach for the social and economic pillars of sustainability needs to be further developed. This paper investigates the application of life cycle costing (LCC) as part of a wider sustainability assessment where also social life cycle assessment (SLCA) and LCA are combined. LCA-type LCC is applied on a case study of remanufactured alternators. Remanufacturing of automobile parts is a fast growing important business with large potential for cost and resource savings. Three design alternatives for the alternator and three locations for the remanufacturing plant are evaluated. The remanufacturer perspective and the user perspective are investigated. The results for the LCA-type LCC show that the largest cost for the remanufacturer is the new parts replacing old warn parts. However, the user cost, and therein especially, cost for fuel used for the alternator's power production dominates and should be the focus for further improvement. In conducting the case study, it was revealed that the connection between the LCA-type LCC results and the economic dimension of sustainability needs to be further investigated and defined. For this purpose, areas of protection for life cycle sustainability assessment and LCA-type LCC in particular need further development.
\end{abstract}


Keywords: automobile generator; alternator; life cycle assessment (LCA)-type life cycle costing (LCC); life cycle sustainability assessment (LCSA); remanufacturing

\section{Introduction}

Sustainability is generally embraced and supported by policy and industry as a necessary path for development. Even though climate change and other pressing environmental problems are of high importance, there is a general consensus that, besides environmental aspects, sustainable development needs to consider also economic and social aspects, as proposed by the Brundtland commission [1]. There is still no widely agreed methodology for how sustainability can be measured. The decision making in the context of sustainability assessments is complex. A large number of requirements, such as technical requirements, disciplines and impact factors have to be taken into account. If attributes of the different possible technological alternatives are left out, the decision may be flawed. This poses challenges on how these three sustainability-dimensions can be measured and integrated on a product level. Starting from an environmental point of view and the life cycle approach, life cycle assessments (LCA) is a widely accepted and standardized method [2,3] for measuring environmental life cycle impacts of products and services. By widening the life cycle thinking to the economic and social dimension of sustainability, the life cycle sustainability assessment (LCSA) has been suggested as a tool for measuring sustainability [4-6]:

$$
\mathrm{LCSA}=\mathrm{LCA}+\mathrm{LCC}+\mathrm{SLCA}
$$

where

LCSA = Life Cycle Sustainability Assessment;

LCA = Environmental Life Cycle Assessment;

LCC = LCA-type Life Cycle Costing;

SLCA $=$ Social Life Cycle Assessment.

While environmental LCA has been in use since the 1960s [7] and standardized since 1997 [8], social life cycle assessment (SLCA) is still in the development process [9]. LCA-type life cycle cost/costing (LCC) is drawing on a long history of conventional LCC dating back as early as the 1930s [10]. However, it is a relatively new tool within sustainability assessment. The SETAC working group on LCC [9] classifies three types of LCC - conventional, environmental and societal LCC - and considers the method of environmental LCC [9] currently regarded as the most suitable for the LCA-type LCC [10-12].

\subsection{Life Cycle Costing in a Sustainability Context}

Unlike the LCA ISO standards [2,3], there are currently no standards available which are valid for LCC of products or services in a sustainability context [13]. There are some product specific standards, where LCC is used in a sustainability context. In the building and construction sector the ISO 15686-5, which is developed for buildings and construction assets, makes a distinction between whole life costs 
and life cycle costs, where the latter are a part of the former. Whole life costs include in addition to the life cycle costs also externalities, non-construction costs and income [14].

LCC has been used in a sustainability context for buildings [14], where life cycle costs are defined as the "cost of an asset or its parts throughout its life cycle, while fulfilling the performance requirements" and life cycle costing as the methodology for the assessment of these costs; "methodology for systematic economic evaluation of life-cycle costs over a period of analysis, as defined in the agreed scope" [14].

The construction sector is the industry where LCC is most widely applied [15]. Goldstein and Eriksson [15] investigated how LCC can play a role in public and private procurement in the Nordic countries and how LCC may be used to measure the profitability of environmentally adapted choices. By applying LCC, it was shown that measurements taken to protect the environment cause no or low extra initial costs, and often were profitable over the life cycle. The report also highlights some practical problems when using LCC in Nordic countries. One is the practice of having different budgets for purchase and for operation and maintenance. These divided budgets result in alternatives with possible higher initial cost than the (purchase) budget permits are not chosen, even though these options may show better environmental and economic performance over the entire life cycle [15].

The building sector is also the object of study by Bragança et al. [16] where the life cycle cost is an indicator besides other sustainability indicators, for assessing the sustainability of buildings and facilitates the decision making [16].

In the automobile sector, Fiksel et al. [17] reported how life cycle cost helped the designers of Chrysler to identify the design option with the lowest life cycle cost, taking not only the direct cost (material and labor) into account, but also hidden and liability costs. In another study of Fiksel et al. [17], inputs to the agricultural systems (crops) were compared taking into account related social, environmental and economic aspects of sustainability. The following economic indicators were chosen: economic value added (manufacturing phase), farmer productivity (bushels/year) (for the use phase) and food costs (\$/bushel) (for distribution phase). Fiksel et al. [17] suggest five categories of product indicators for the economic dimension of sustainability:

- direct costs (raw material cost, labor cost and capital cost),

- potentially hidden costs (recycling revenue and product disposition cost),

- contingent costs (employee injury cost and customer warranty cost),

- relationship costs (loss of goodwill and business interruption) and

- externalities (loss of ecosystem productivity and resources).

For other products, LCC studies in a sustainability context are rare, but have been applied as a method for improving the sustainability of fishing vessel design on a micro level and fisheries management on a macro level [18].

Hunkeler et al. [9] define environmental LCC as "An assessment of all costs associated with the life cycle of a product that are directly covered by any one or more of the actors in the product life cycle (e.g., supplier, manufacturer, user or consumer, or EoL actor) with complementary inclusion of externalities that are anticipated to be internalized in the decision-relevant future (...). Environmental LCC has to be accompanied by a life cycle assessment and is a consistent pillar of sustainability." This definition is considered as the current state of the art and starting point of LCA-type LCC. 
This paper reports results from a case study where LCA-type LCC has been used to assess three different design alternatives and three different location options for the remanufacturing of an automotive electrical generator (alternator).

\subsection{Alternator Remanufacturing}

The function of the alternator is to generate electrical energy for the battery and the electrical equipment in the vehicle. This is done by transforming rotation energy from the power train (driven by the motor) to electrical energy [19,20].

Remanufacturing of used vehicle parts (named "cores" [21-23]) is a large industry that globally embraces 100,000 companies employing 500,000 people with an annual turn-over of $10^{14}$ Euro [24]. As a response to end-of-life regulation, aiming at preventing the material to be sent to a landfill, remanufacturing is an alternative to material recycling and energy recovery. This is especially clear in the automotive industry with its large turnover. The demand for remanufacturing automotive parts is growing in the United States and Europe, despite a stagnating aftermarket as a whole [25]. The alternator is the automotive part with the highest remanufacturing volume [26].

Earlier studies have indicated that remanufacturing of automotive parts is generally beneficial from an environmental point of view. Not only are the materials kept in closed loop such that raw materials extraction is saved (material recycling), but also the energy intensive manufacturing of the parts are eliminated. This means a double benefit where both energy and material resources are saved compared to new parts production [27-32]. Even though there are challenges to overcome, like the supply of a sufficient number of used products to be remanufactured [21,32], the consumers of the remanufactured part have an economic saving in the range of $30 \%$ [25] to 53\% [28] compared to a new product.

\section{Method and Data}

Even though the LCC is noted in literature since the 1930s, no standardized method exists [33], but rather a range of different approaches [13]. Dhillon [34] lists ten general LCC models and thirteen specific LCC models. They range from relatively simple models taking two types of cost into account, recurring and non-recurring cost (general life cycle cost model II) to specific life cycle cost models with a range of different cost elements [34] .

The LCC approach developed by Bubeck [35] considered in analogy to the LCA method an individual automobile part as a reference object. This approach was applied in the present case study and requires a structuring of the costs according to where they occur over the life cycle stages and the focus on money flows (in analogy to material and energy flows) [35].

Asiedu and $\mathrm{Gu}$ [36] describe three different cost estimating models for manufacturing: parametric models, analogous models and detailed models. The case study described in this paper uses the detailed model, which is also known as the bottom-up estimating model. This model was chosen here since it - though time-consuming and costly-according to Asiedu and $\mathrm{Gu}$ [28] gives the most accurate cost estimates. With the starting point of a detailed labor time and rates in addition to material quantities and prices, direct costs can be estimated. Allocation rates are used for indirect and overhead costs. Asiedu and $\mathrm{Gu}[36]$ operate with three different life cycle approaches. These are [36]: 
(1) a product point of view, where the life cycle starts with the identification of needs, and includes the design, production, use and ends with the disposal;

(2) a process point of view, where the life cycle starts with the manufacturing system design, extends through manufacturing, operation and recycling processes;

(3) a logistic support point of view, which includes the support of system design, maintenance and recycling.

The current study has a product point of view, but starts with the raw material extraction in line with the LCA methodology.

In LCA and also in the LCA-type LCC all phases ("from the cradle to the grave") of the life cycle of a product or a service - from the extraction and processing of the resources, through production and further processing, distribution and transport, use and consumption to recycling and disposal-are considered [4]. In these approaches the physical material and energy flows are in focus. Rebitzer and Nakamura [11] argue that other elements typically included in conventional LCC - like research and development, marketing campaign, infrastructure and machinery-could be regarded as included in environmental LCC, if these are considered to contribute more than a certain percentage/threshold to the total life cycle costs (typically a cut off of $5 \%$ is accepted) [11].

A procedure to carry out an LCA-type LCC as part of a wider sustainability assessment (LCSA) is illustrated in Figure 1. The starting point for the LCSA is to describe the goal and scope of the study as specified in the LCA standards [2,3]. This leads to the choice of functional unit and related reference flow.

A detailed life cycle inventory is necessary for conducting LCSA. The life cycle inventory encompasses all inputs and outputs of the system like materials, waste and energy flows [37]. This inventory can be used as a starting point for the life cycle costing and, when needed, supported by (other) conventional LCC elements.

Figure 1. Procedure used for LCA-type LCC as part of a wider sustainability assessment (Based on $[11,38])$.

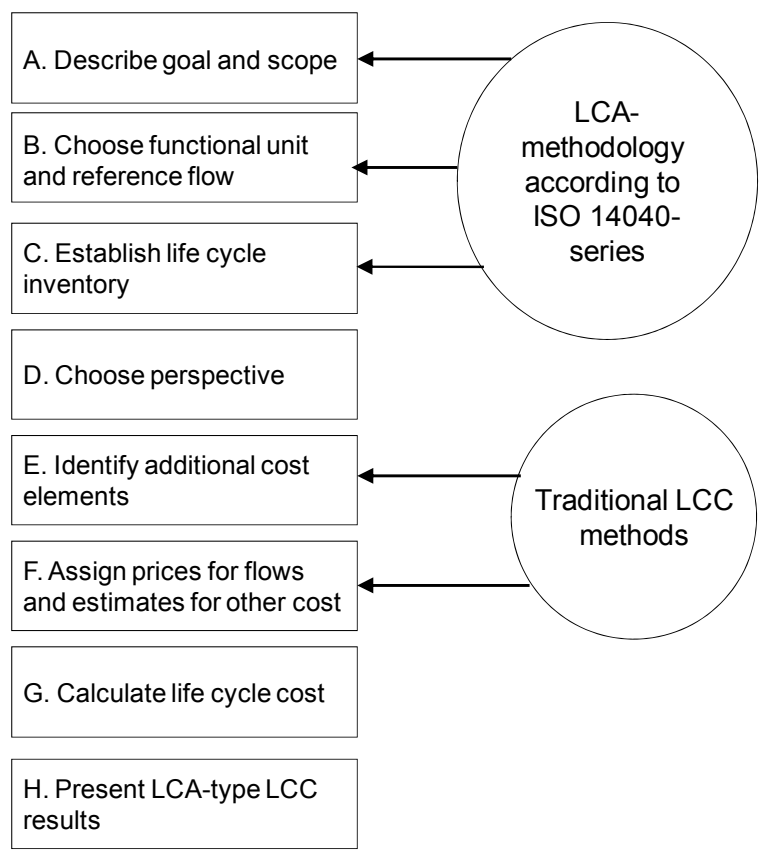




\subsection{Case Study-Remanufactured Alternator}

The case study on LCC for remanufacturing alternators is based on following conditions: A mini-plant for remanufacturing generators is organized as a micro enterprise inside a container, equipped with remanufacturing modules (like working place for disassembly and assembly, cleaning and test facilities) and ready to be used. The container is of type standard 20 or 40 feet and can be equipped with additional modules, like an energy module, which allows the operation of the mini-factory also where electricity cannot be provided from a grid. Therefore the mini-factory is extremely mobile and can operate globally in developed as well as developing regions [39,40].

Different, and sometimes even contrary, design targets have to be balanced during development of a product like the alternator in this study (design to cost, design for service, design for assembly, design for recycling and design for $\mathrm{X}[32,41])$. This may complicate-especially for independent companies - reuse and remanufacture of parts [42]. However, if the original equipment manufacturer (OEM) increasingly remanufacture their own products, the design of the automotive part is likely to be developed in a direction that makes reuse and remanufacturing more straightforward [43]. In the case study, examined in this paper, a design team is included in order to identify different design alternatives for an automotive part.

\subsubsection{Goal and Scope of the Case Study}

The goal and scope of this LCC study is to perform an economic analysis (as part of a wider sustainability analysis including LCA and SLCA) of three different design alternatives for an automobile generator-the alternator. The three design options are described in more detail in Section 2.1.2. In addition, three different locations for the mini-factory where the remanufacturing process of alternators takes place will be evaluated. Therefore, also the transport costs need to be taken into account.

The generator is capable of providing the battery and electrical equipment in a mid-size modern vehicle with enough electric power during the life time of the vehicle (set to 13 years and 200,000 km based on $[19,44])$.

The perspectives of the remanufacturer and the user of the remanufactured generator have been chosen. The remanufacturer decides which design they want to implement, and also in which location they want to place the remanufacturing site. However, earlier LCA studies of generators have shown that the use phase is most important because of the energy used for the power production [45], which is why this phase should be included in a life cycle sustainability assessment as well. As the second use phase of the remanufactured alternator takes place in a vehicle that already have been used for a while, the life time of the vehicle, and not the remanufactured alternator constrains the second use phase. Therefore, in the calculation of the second use phase, we assume that the remanufactured alternator is used $100,000 \mathrm{~km}$ before the alternator is scrapped with the vehicle. Therefore, the functional unit in this study is $100,000 \mathrm{~km}$. This will be reached by the reference flow of one alternator being capable of generating $1.4-1.6 \mathrm{~kW}$ power (1.5 kW in average and used in the calculations).

This paper focuses on the product level with a case study of a generator being remanufactured. The connection to sustainability on a broader level is discussed in Chapter 5 Outlook. Figure 2 shows the model of the life cycle of the alternator. The blue shaded areas indicate the perspectives chosen for the 
LCA-type LCC: the remanufacturer perspectives, with remanufacturing taking place in Germany, India or Sierra Leone and the user perspectives, which take place in Germany. Thereby for India and Sierra Leone locations, additional oversea transport is needed.

Figure 2. Life cycle of the alternator. The LCC perspectives chosen are indicated by blue areas.

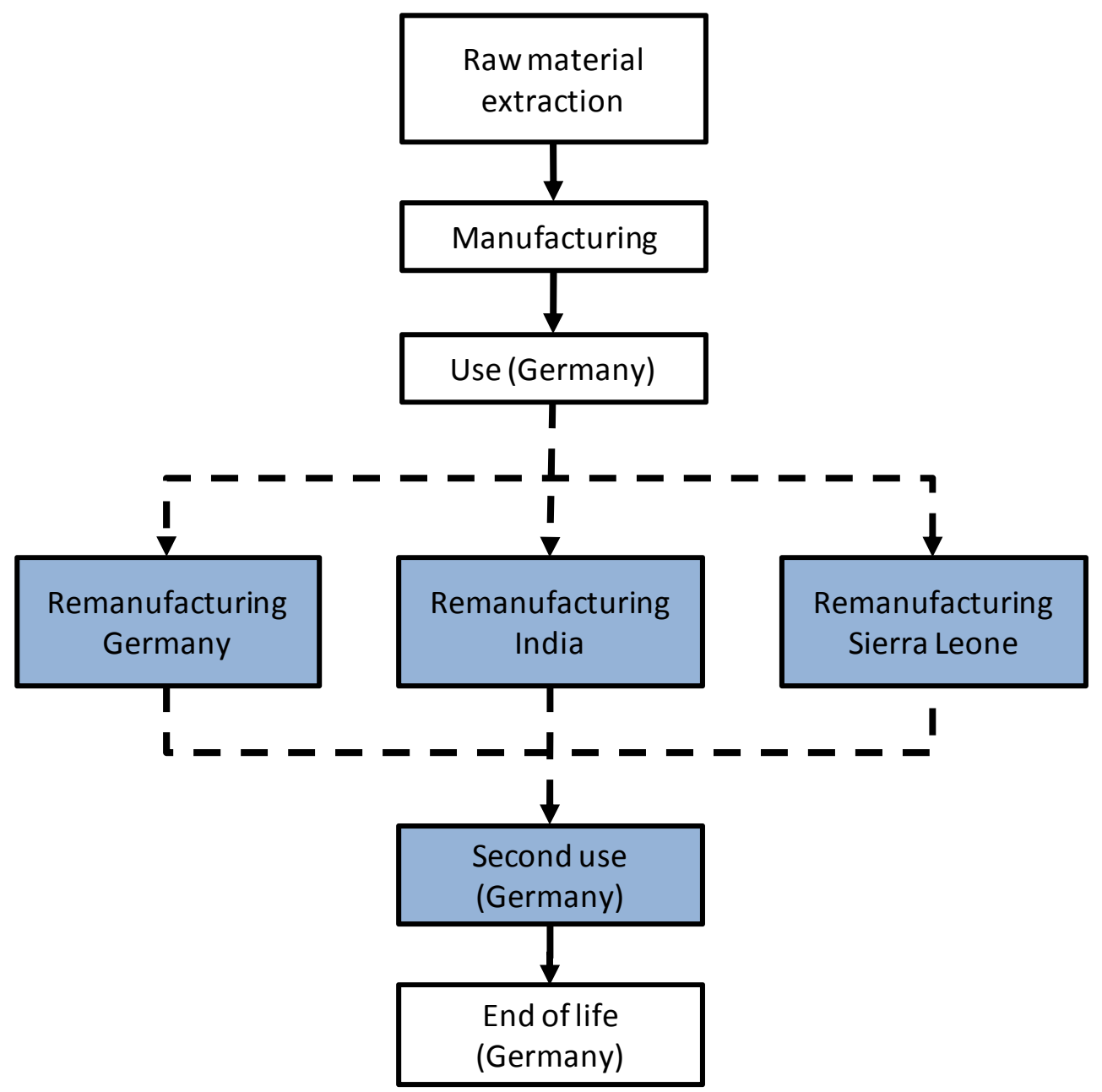

\subsubsection{The Remanufacturer Perspective}

The remanufacturing process consists of [26,27]: incoming inspection of the used generator, disassembly, cleaning, inspection and sorting of used parts, reconditioning and replacement, reassembly and final testing. Remanufacturing requires labor, energy and new parts where the old ones need to be replaced. The remanufacturing perspective is thereby similar to that of manufacturing with some additional steps for example reassembling of the used part and cleaning.

LCA-type LCC from the remanufacturer perspective can be used to provide an estimate of which costs occur for different design alternatives and location choices, and thereby help to identify opportunities to reduce the cost. Together with LCA and SLCA, the LCC can be used to assess the sustainability of these designs alternatives and location choices and provide a basis for decision-making. 
The three design alternatives for the alternator: conventional, light weight and ultra light weight generator are shown in Table 1. The different parts of the generator, the material, weight and replacement probability [46] in the remanufacturing are given as well. The differences from the conventional alternator are highlighted. These new replacement probabilities are assumptions made by the design team. The light weight materials in design alternative 2 and 3 have a shorter durability than the conventional materials. Therefore, all the plastic parts and 4 out of 10 aluminum housings are assumed to be changed in the remanufacturing process. However, as described in Section 2.1.1., remanufactured alternators are mostly installed in used vehicles. Thus, we assume that also the less durable parts, like the plastic parts, hold for the second use phase and that an additional repair is not required.

Table 1. Materials, weight and replacement probability [46] in the remanufacturing process for the generator parts in the three design alternatives (differences are highlighted).

\begin{tabular}{|c|c|c|c|c|c|c|c|c|c|}
\hline \multirow[b]{2}{*}{ Part } & \multicolumn{3}{|c|}{$\begin{array}{c}\text { Design Alternative } 1 \\
\text { - Conventional Generator }\end{array}$} & \multicolumn{3}{|c|}{$\begin{array}{c}\text { Design Alternative } 2 \\
\text {-Light Weight Generator }\end{array}$} & \multicolumn{3}{|c|}{$\begin{array}{c}\text { Design Alternative } 3 \\
\text {-Ultra Light Weight Generator }\end{array}$} \\
\hline & Material & $\begin{array}{c}\text { Weight } \\
{[\mathrm{kg}]}\end{array}$ & $\begin{array}{c}\text { Replacement } \\
\text { Probability }\end{array}$ & Material & $\begin{array}{c}\text { Weight } \\
{[\mathrm{kg}]}\end{array}$ & $\begin{array}{c}\text { Replacement } \\
\text { Probability }\end{array}$ & Material & $\begin{array}{c}\text { Weight } \\
{[\mathrm{kg}]}\end{array}$ & $\begin{array}{c}\text { Replacement } \\
\text { Probability }\end{array}$ \\
\hline Stator & Steel & 0.773 & $20 \%$ & Steel & 0.773 & $20 \%$ & Steel & 0.773 & $20 \%$ \\
\hline Rotor Coil & Copper & 0.550 & $22 \%$ & Copper & 0.550 & $22 \%$ & Copper & 0.550 & $22 \%$ \\
\hline Rotor & Iron Cast & 1.094 & $19 \%$ & Iron Cast & 1.094 & $19 \%$ & Iron Cast & 1.094 & $19 \%$ \\
\hline Drive Shaft & Steel & 0.262 & $10 \%$ & Steel & 0.262 & $10 \%$ & Steel & 0.262 & $10 \%$ \\
\hline Belt Fitting & Steel & 0.519 & $10 \%$ & Steel & 0.519 & $10 \%$ & Aluminum & 0.180 & $75 \%$ \\
\hline Fan & Steel & 0.138 & $10 \%$ & Plastic/PP & 0.016 & $100 \%$ & Plastic/PP & 0.016 & $100 \%$ \\
\hline Spacer & Aluminum & 0.003 & $50 \%$ & Aluminum & 0.003 & $50 \%$ & Aluminum & 0.003 & $50 \%$ \\
\hline Bearings & Rolled Steel & 0.099 & $50 \%$ & Rolled Steel & 0.099 & $50 \%$ & Plastic/PP & 0.011 & $100 \%$ \\
\hline Slip Ring N & Copper & 0.033 & $100 \%$ & Copper & 0.033 & $100 \%$ & Copper & 0.033 & $100 \%$ \\
\hline Slip Ring S & Copper & 0.071 & $100 \%$ & Copper & 0.071 & $100 \%$ & Copper & 0.071 & $100 \%$ \\
\hline Housing & Iron Cast & 2.527 & $15 \%$ & Aluminum & 0.958 & $40 \%$ & Aluminum & 0.958 & $40 \%$ \\
\hline \multicolumn{2}{|c|}{ Total } & 6.069 & & & 4.378 & & & 3.952 & \\
\hline
\end{tabular}

For the calculation of the life cycle costs labor costs and material costs have been considered and are described in the following.

The labor times for the different steps in the remanufacturing process has been estimated with the Methods-Time-Measurement (MTM) method [47,48]. The remanufacturing time is about 16.5 min; the difference between the investigated design alternatives is a few seconds. The labor rates were gained from scientific literature [49] country and labor statistics [50-52] and the International Labor Organizations-database on wage [53]. 2008 as a reference year has been chosen:

- Germany: 24.50 Euro/h [52];

- India: 0.86 Euro/h (2008-estimate based on [49,51,53,54]);

- Sierra Leone: 0.96 Euro/h [50].

Currency exchange rates for Sierra Leone Le and Indian Rupee have a large influence of the labor costs in Euro. With a $10 \%$ estimate for non-productive time, the labor $\cos t \mathrm{C}_{\mathrm{L}}$ can be calculated according to the Equation (2): 


$$
\mathrm{C}_{\mathrm{L}}=\mathrm{t}_{\mathrm{p}} \times \mathrm{P}_{\mathrm{L}} \times 1.1
$$

where $\mathrm{t}_{\mathrm{p}}=$ remanufacturing time, and $\mathrm{P}_{\mathrm{L}}=$ Labor rates per working hour.

Based on a detailed figure of the generator's design and the data shown in Table 1, the material quantities have been determined. Material prices are obtained from literature $[55,56]$.

Transport costs include the distribution of the alternator to the user in Germany, but for India and Sierra Leone also additional oversea transport. The costs associated with export from Germany to India and Sierra Leone (1000 cores in one container) and import to Germany from India and Sierra Leone (900 remanufactured alternators in one container) are derived from [57] and include costs for documents, customs clearance and technical control, broker fees, terminal handling charges and inland transport [58]. The ocean transport costs are derived from [59].

The life cycle costs from the remanufacturer perspective, $\mathrm{LCC}_{\mathrm{RM}}$ can be calculated according to Equation (3) and are presented in Figure 3 and Table 2 in Section 3.1.:

$$
\mathrm{LCC}_{\mathrm{RM}}=\mathrm{C}_{\mathrm{AU}}+\mathrm{C}_{\mathrm{SP}}+\mathrm{C}_{\mathrm{C}}+\mathrm{C}_{\mathrm{L}}+\mathrm{C}_{\mathrm{T}}+\mathrm{C}_{\mathrm{P}}+\mathrm{C}_{\mathrm{O}}
$$

where

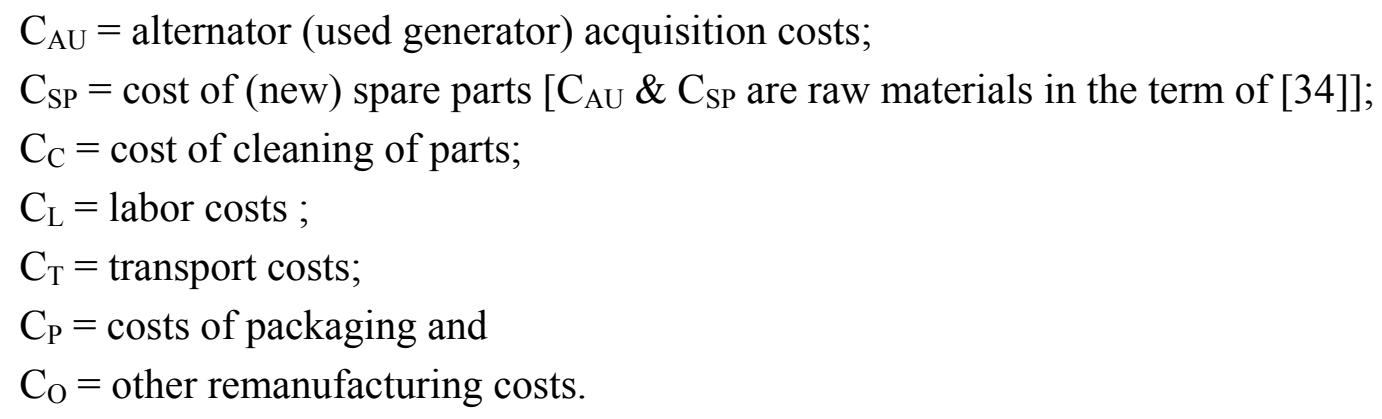

where

$\mathrm{C}_{\mathrm{W}}=$ costs for warranties;

$\mathrm{C}_{\mathrm{MR}}=$ maintenance and repair;

$\mathrm{C}_{\mathrm{DO}}=$ direct overhead costs;

$\mathrm{C}_{\mathrm{IO}}=$ indirect overhead costs;

$\mathrm{C}_{\mathrm{D}}=$ depreciation;

$\mathrm{C}_{\mathrm{I}}=$ insurance.

\subsubsection{The User Perspective}

The costs for the remanufactured generator occur not only for the acquisition, but mainly in the use phase of the alternator.

The life cycle costs from a user's perspective can be calculated according to Equation (4) based on [34,35] and are presented in Table 3, Section 3.2:

$$
\mathrm{LCC}_{\mathrm{User}}=\mathrm{C}_{\mathrm{AU}}+\mathrm{C}_{\mathrm{F}}+\mathrm{C}_{\mathrm{MR}}+\mathrm{C}_{\mathrm{ILF}}+\mathrm{C}_{\mathrm{D}}-\mathrm{C}_{\mathrm{SAL}}
$$

where

$\mathrm{C}_{\mathrm{AU}}=$ generator acquisition cost (price of remanufactured generator)

$\mathrm{C}_{\mathrm{F}}=$ fuel costs 
$\mathrm{C}_{\mathrm{MR}}=$ costs of repair and maintenance

$\mathrm{C}_{\mathrm{lLF}}=$ costs associated with insurance, license, and fees

$\mathrm{C}_{\mathrm{D}}=$ disposal costs

$\mathrm{C}_{\mathrm{SAL}}=$ salvage value

For the specific purpose of the different design alternatives of the generator, the fuel cost $\mathrm{C}_{\mathrm{F}}$ is further broken down into weight induced fuel cost $\mathrm{C}_{\mathrm{FW}}$ and fuel costs for power production $\mathrm{C}_{\mathrm{FP}}$.

The weight induced fuel cost can be calculated according to

$$
\mathrm{C}_{\mathrm{FW}}=\mathrm{F}_{\text {weight }} \times \mathrm{P}_{\text {fuel }}
$$

where weight induced fuel use is based on [60]:

$$
\mathrm{F}_{\text {weight }}=0.15[\mathrm{~L} /(100 \mathrm{~km} 100 \mathrm{~kg})] \times \mathrm{D}[\mathrm{km}] \times \mathrm{m}_{\mathrm{g}}[\mathrm{kg}]
$$

$\mathrm{D}$ is the distance in $\mathrm{km}$ and $\mathrm{m}_{\mathrm{g}}$ is the weight in $\mathrm{kg}$ of the automobile part.

The fuel costs for power production can be calculated according to

$$
\mathrm{C}_{\mathrm{FP}}=\mathrm{F}_{\text {power }} \times \mathrm{P}_{\text {fuel }}
$$

where fuel use for power generation is based on $[61,62]$ :

$$
\mathrm{F}_{\text {power }}=\frac{\mathrm{D}[\mathrm{km}] \times \mathrm{P}_{\text {out }}[\mathrm{kw}] \times 3.6[\mathrm{MJ} / \mathrm{kWh}] \times \mathrm{c}_{\mathrm{d}}}{\mathrm{v}[\mathrm{km} / \mathrm{h}] \times \eta_{\mathrm{g}} \times \eta_{\mathrm{m}} \times \rho_{\text {gasoline }}[\mathrm{kg} / \mathrm{L}] \times \mathrm{H}_{\mathrm{u}}[\mathrm{MJ} / \mathrm{kg}]}
$$

The values and parameter used for the calculations in the use phase are given in Table 4.

Table 4. Parameters used for the life cycle costing (LCC) calculation of the second user perspective.

\begin{tabular}{lcccc}
\hline Parameter & & Value & Unit & Source \\
\hline Total distance & $\mathrm{D}$ & 100,000 & {$[\mathrm{~km}]$} & Functional unit, based on [45] \\
Power output (generator) & $\mathrm{P}_{\text {out }}$ & 1.5 & {$[\mathrm{~kW}]$} & Specification \\
Deceleration phases $(15 \%)$ coefficient & $\mathrm{c}_{\mathrm{d}}$ & 0.85 & & {$[60]$} \\
Average speed NEDC & $\mathrm{V}$ & 33.6 & {$[\mathrm{~km} / \mathrm{h}]$} & {$[60]$} \\
Energy efficiency generator & $\eta_{\mathrm{g}}$ & 0.56 & & Based on $[19,45,62]$ \\
Motor energy efficiency & $\eta_{\mathrm{m}}$ & 0.42 & & Based on $[60,62]$ \\
Density gasoline & $\rho_{\text {gasoline }}$ & 0.75 & {$[\mathrm{~kg} / \mathrm{L}]$} & {$[60]$} \\
Energy content gasoline & $\mathrm{H}_{\mathrm{u}}$ & 43.5 & {$[\mathrm{MJ} / \mathrm{kg}]$} & {$[60]$} \\
Price for gasoline & $\mathrm{P}_{\text {fuel }}$ & 1.479 & {$[€ / \mathrm{L}]$} & {$[63]$} \\
\hline
\end{tabular}

Modern alternators have a life time of more than $200,000 \mathrm{~km}$, such that maintenance and repair is not necessary [19]. However, as remanufactured alternators are mainly used as replacement alternators in used vehicles, we assume that the vehicle with the remanufactured alternator is scrapped after $100,000 \mathrm{~km}$.

Following [35] the insurance, licenses and fees in the use phase for an automotive part is insignificant. The $\mathrm{C}_{\mathrm{ILF}}$ are therefore set to be 0 . The user has the option to deliver the used alternator to the remanufacturer and get paid 40 Euro. This is the most feasible end of life option for the user, such that disposal cost is not further regarded in this study. (From Table 1 can be derived that $10 \%$ of the core cannot be used further in the remanufacturing. This implies that the life time of a core is not 
infinite, and at some point, the end of life has to be considered, but then rather to be paid by or as an income (e.g., for scrap metals) for the remanufacturer.)

\section{Result}

\subsection{Life Cycle Costs from the Remanufacturer Perspective}

The life cycle costs for the remanufacturer are shown in Table 2 and Figure 3. The alternator acquisition cost is estimated at 40 Euro for all three design alternatives in the three assessed locations, Germany, India and Sierra Leone. Independent of the locations, the cost of new spare parts constitutes the largest remanufacturer costs, from 88 Euro for the conventional alternator to 127 Euro for the ultra light weight alternative $3[46,55,56]$. The labor costs for the conventional alternator are, as expected, highest in Germany with a maximum of 7.43 Euro and lowest in India with 0.26 Euro. The difference in labor costs between the different alternatives are however minimal. The resulting sums of costs from the remanufacturer perspective are almost similar in the three assessed locations, since the higher transport/shipping costs in India and Sierra Leone (Euro 14.49 and 14.92 respectively compared to 7.92 in Germany) almost balance the higher labor costs in Germany.

Table 2. LCC results from the remanufacturer perspective (Euro).

\begin{tabular}{|c|c|c|c|c|c|c|c|c|c|}
\hline \multirow{2}{*}{ Type of costs } & \multicolumn{3}{|c|}{ Germany } & \multicolumn{3}{|c|}{ India } & \multicolumn{3}{|c|}{ Sierra Leone } \\
\hline & Alt 1 & Alt 2 & Alt 3 & Alt 1 & Alt 2 & Alt 3 & Alt 1 & Alt 2 & Alt 3 \\
\hline $\mathrm{C}_{\mathrm{AU}} \begin{array}{l}\text { Used alternator } \\
\text { aquisition costs }\end{array}$ & & 40.00 & & & 40.00 & & & 40.00 & \\
\hline $\begin{array}{l}\mathrm{C}_{\mathrm{SP}} \begin{array}{l}\text { Cost of (new) spare } \\
\text { parts }\end{array}\end{array}$ & 88.31 & 110.94 & 127.16 & 88.31 & 110.94 & 127.16 & 88.31 & 110.94 & 127.16 \\
\hline $\mathrm{C}_{\mathrm{C}} \begin{array}{l}\text { Cost of energy for } \\
\text { cleaning }\end{array}$ & 2.70 & 1.95 & 1.76 & 0.78 & 0.56 & 0.51 & 2.33 & 1.68 & 1.52 \\
\hline $\mathrm{C}_{\mathrm{L}}$ Labor costs & 7.43 & 7.39 & 7.37 & 0.26 & 0.26 & 0.26 & 0.29 & 0.29 & 0.29 \\
\hline $\mathrm{C}_{\mathrm{T}}$ Transport costs & & 7.92 & & & 14.49 & & & 14.92 & \\
\hline $\mathrm{C}_{\mathrm{W}}$ Cost for warranties & 1.45 & 1.68 & 1.85 & 1.35 & 1.59 & 1.76 & 1.35 & 1.59 & 1.76 \\
\hline $\begin{array}{l}\text { Life cycle cost } \\
\text { remanufacturer }\end{array}$ & 147.80 & 169.88 & 186.06 & 145.18 & 167.84 & 184.17 & 147.20 & 169.43 & 185.65 \\
\hline
\end{tabular}

The cost of energy for cleaning (maximum 2.70 Euro, conventional alternator, Germany) and costs for warranties are for all assessed design alternatives and locations of less importance. The reason why the cost of energy for cleaning in Sierra Leone is almost as high as in Germany, is that an own diesel driven aggregate is needed here to ensure a continuous electricity supply. 
Figure 3. Life cycle costs from the remanufacturer perspective.

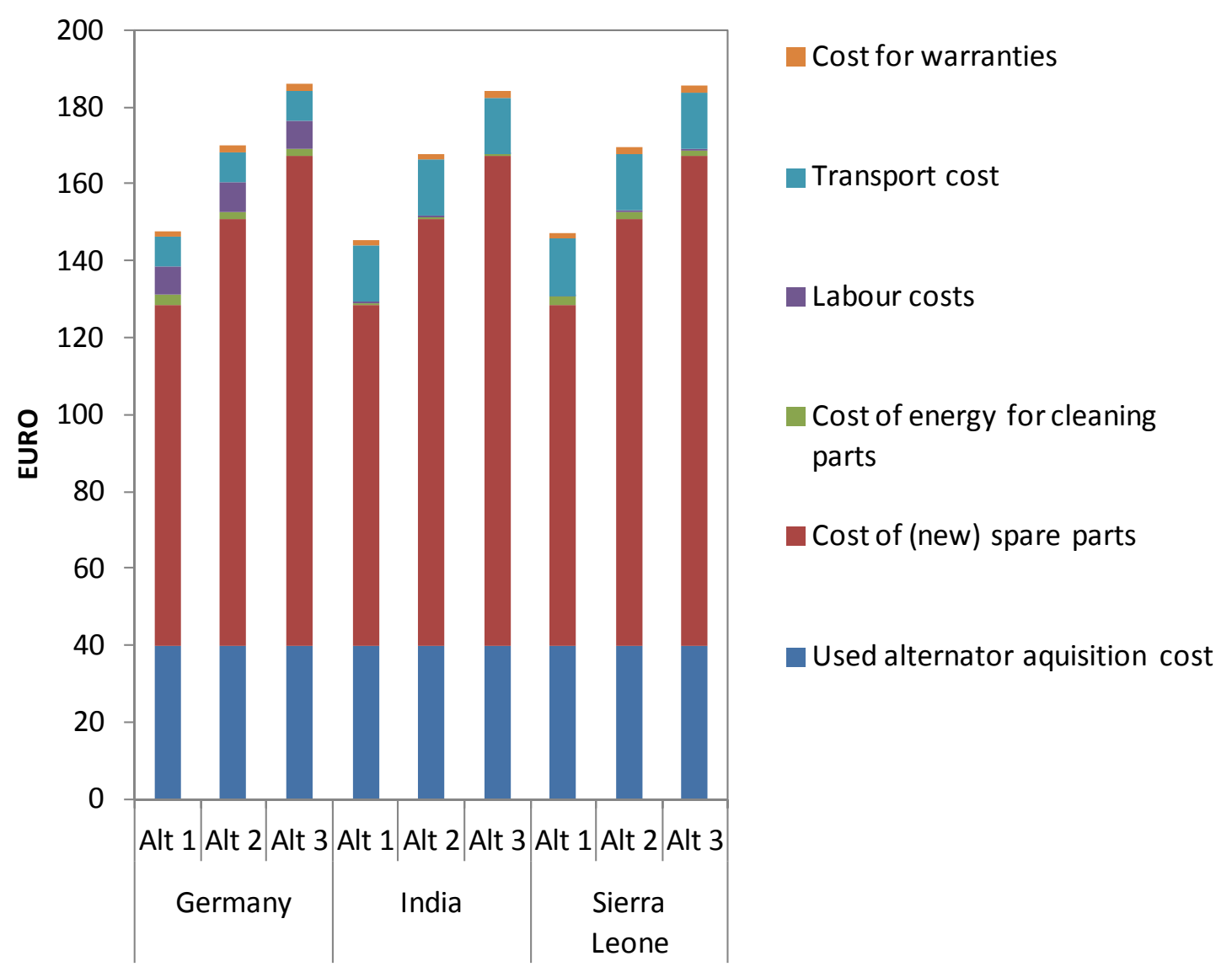

\subsection{Life Cycle Cost from the User Perspective}

The costs for the user are described in Section 2.1.3. Figure 4 and Table 3 show the life cycle costs from a user's perspective. The fuel use costs for power production dominates with 2,633 Euro in all design alternatives. Compared to those costs the weight induced fuel costs are marginal, ranging from 9 Euro (ultra light weight alternative) to 13 Euro (conventional alternator). This fuel cost saving when using the light weight alternative vanishes, taking into account the generator acquisition costs. The low acquisition cost $(\approx 250$ Euro) for the conventional alternator makes this the best LCC option from the user perspective. The salvage value is 40 Euro for all design alternatives, marked red in Table 3 and illustrated below the first axes in Figure 4 to indicate that it is a negative cost and thereby an income for the user of the alternator.

The life cycle costs have been calculated using a steady-state model (assuming a discount rate of 0 ), which is most compatible with environmental LCA and the approach used in environmental LCC [64]. 
Figure 4. LCC results from the user perspective.

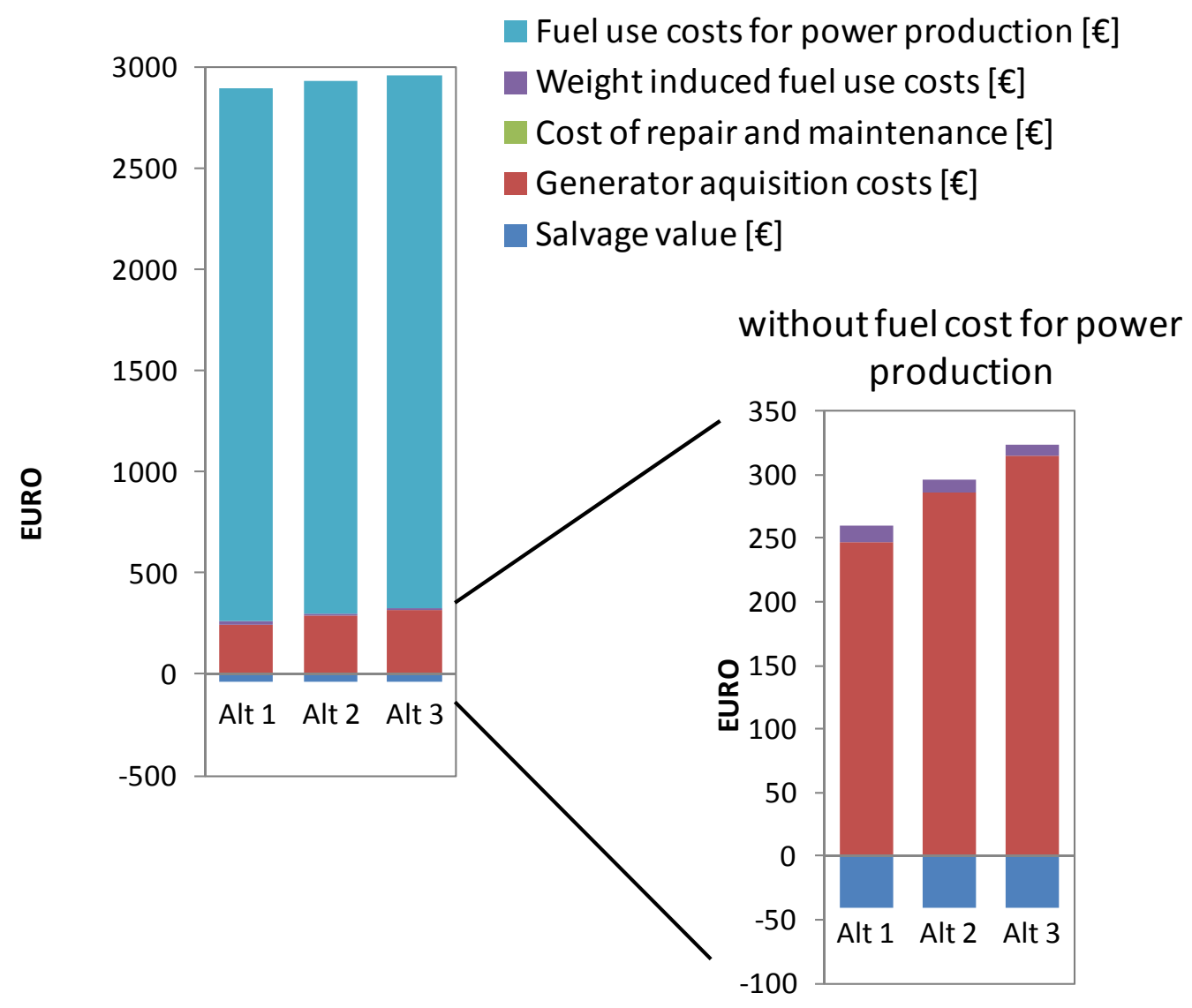

Table 3. LCC results from the user perspective [Euro].

\begin{tabular}{llccc}
\hline & Type of costs & Alt. 1 & Alt. 2 & Alt. 3 \\
\hline $\mathrm{C}_{\mathrm{AU}}$ & Alternator acquisition cost & 247 & 286 & 315 \\
$\mathrm{C}_{\mathrm{FW}}$ & Weight induced fuel use cost & 13 & 10 & 9 \\
$\mathrm{C}_{\mathrm{PW}}$ & Fuel use cost for power production & 2633 & 2633 & 2633 \\
$\mathrm{C}_{\mathrm{ILF}}$ & Cost for insurance, licensees and fees & 0 & 0 & 0 \\
$\mathrm{C}_{\mathrm{MR}}$ & Cost of repair and maintenance & 0 & 0 & 0 \\
$\mathrm{C}_{\mathrm{SAL}}$ & Salvage value & 40 & 40 & 40 \\
LCC $_{\text {USER }}$ & Life cycle cost in use phase & $\mathbf{2 8 5 4}$ & $\mathbf{2 8 8 9}$ & $\mathbf{2 9 1 6}$ \\
\hline
\end{tabular}

\section{Discussion and Recommendation}

The preceding paragraph presents the results of a LCA-type LCC-study of remanufactured alternators. The perspectives chosen are that of the remanufacturer and the user of the remanufactured alternator. A full LCC would include all costs from raw material (extraction) over remanufacturing to end of life. However, as the acquisition cost of the remanufactured alternator is a cost for the user and at the same time an income for the remanufacturer (ex taxes), the costs cannot be summed [10]. Instead, life cycle costs for two different perspectives, that of the remanufacturer and that of the user of the alternator are shown. 
The LCC results from a remanufacturer's perspective show that the life cycle costs for remanufacturing an alternator are lowest, for all alternator designs, when the remanufacturing plant is located in India, but the difference between the different locations are minimal. This is due to the transport/shipping costs and, especially for Sierra Leone, the associated costs for import and export that balance out the higher German labor costs. However, this is only true if the alternator is used in Germany and the costs for other parts are the same as modeled here. From an LCC point of view, remanufacturing seems to be most cost-effective, when done at that place where the generator is used, as transport/shipping cost of cores and remanufactured parts thereby can be minimized. With regard to the mini-plant in a mobile container ready to be used anywhere, this looks like an interesting model for remanufacturing.

The labor costs, though much higher in Germany compared to India and Sierra Leone, play a minor role over the life cycle compared to costs for new spare parts and used alternators, which was surprising with regard to an industry that is normally considered as being labor intensive [65]. The labor costs depend on the wages paid and the value of the local currency. With regard to future developments concerning wages paid in the manufacturing sector, a light increase can be observed in Germany. A future increase is expected as well in India - where wages already doubled from 2005 to 2006 [66] and in Sierra Leone. The wage increase can however, from a social point of view (in the SLCA) be considered as a positive impact. It could have a more meaningful impact in SLCA than in the LCA-type LCC, as the labor costs play a minor role for the overall LCA-type LCC results.

With regard to the design alternatives, differences in the life cycle costs are mainly induced by the costs for (new) spare parts. That means, that if they cost less or more in Sierra Leone or in India, the results could be different. The conventional alternator was identified to be the alternative with less life cycle costs, due to its lower costs for new spare parts.

From a user's perspective, main costs over the generator's life cycle are fuel costs. The initial higher price of the light weight alternators are not offset in lower weight induced fuel use. This probably holds, also if the price for fuel increases in the future. Therefore, from the user's perspective, the ideal alternator design is the conventional one.

These conclusions refer only to the economic aspects of remanufacturing alternators and their subsequent use. Evaluating the remanufacturing of alternators from a sustainability perspective, environmental as well as social aspects, gained by LCA and SLCA have to be taken into account. This is going to be investigated by the authors.

From an LCA-type LCC perspective, showing that main costs over the life cycle of a generator occur due to fuel consumption for power production, the recommendation to the designers is to design a generator that is an effective power producer, and to make sure that remanufacturing does not decrease the power production effectiveness, but results in the same (as modeled in this case study) or even better increase of the effectiveness. Remanufacturing time and material weight are less critical regards to the life cycle costs, such that even though the remanufacturing process is more complicated and hence time consuming, the effort should be directed on better electricity production efficiency. For the generator, this means that the clearance between the rotor and stator should be as small as possible. The design and the remanufacturing should contribute to this aim. In a trade off situation material choice and labor effort should underpin this aim. 
According to the findings from the case study from an LCA-type LCC perspective, aiming at reducing costs over the life cycle, following recommendations can be drawn:

(1) improving the design of generators for a higher effectiveness of power-production;

(2) locating the remanufacturing plant where generators to be remanufactured are used (only Germany was investigated in this study) and

(3) increase the use of remanufactured generators (if remanufactured alternators are as energy effective as new one, which is assumed here based on [67] but should be validated in further research).

However, as there might be a conflict between recommendation 1, of designing the generators for higher power-production effectiveness, and recommendation 3, of increasing the use of remanufactured generators, more research is needed on the actual life cycle performance of new generators and remanufactured generators. Where data are available, a comparison between new alternators and manufactured alternators should be investigated over the life time.

The effects of the recommendations (fuel savings, less transport and keeping the product in a closed loop) can be assumed to be positive also for the environment, and will be investigated with an environmental LCA. Also the social aspects of the remanufactured alternators and especially the social impacts related to the location choice for the remanufacturing mini-factory are areas for further research.

\section{Outlook-LCC in a Sustainability Context}

The case study was conducted using a LCA-type LCC for a product. This approach is intended to be used to measure the economic dimension within a sustainability assessment of products (LCSA). The presented case study raises three areas for further development of LCA-type LCC:

- Case studies, showing which of the various costs, addressed in theoretical approaches are actually included in practice as well as to provide more data.

- Data access - while prices often are accessible, the costs behind are often confidential, and databases for costs (similar to LCA-databases) do not exist yet.

- Contribution of the LCA-type LCC to address the economic dimension of sustainable development.

In a sustainability context, not only the cost of a product occurring over its life cycle but also the economic benefit or the value added (for the society) should be regarded. It is also relevant to ask how economic costs are related to the economic dimension of sustainability — is a cost negative or positive? The Brundtland report [1] considers economic growth to be essential at least in parts of the world where basics needs are not being met (Sierra Leone would be a clear candidate and India probably too). A cost would likely increase the gross domestic product (GDP). GDP is an important indicator used to measure economic growth [68]. A conflict between the microeconomic aim of reducing cost and the higher level goal of economic growth seems to exist. However, economic growth should be recognized more as a mean to an end rather than an end itself. Therefore, economic growth is probably not the only purpose of LCA-type LCC. Overall areas of protection (AoP) could be of help. AoP, also called safeguard subjects have well recognized values for the society [69]. The ultimate goal for 
sustainable development - from an anthropocentric view - is human wellbeing of current and future generations. LCA-type LCC considers economic costs and the AoP could be economic wellbeing. However, what economic wellbeing means for the individuals is difficult to decide.

On a macro level, economic growth is the most frequent used, but not perfect, measurement of economic wellbeing. Further, economic wellbeing is not enough for a sustainable development. Also an intact environment is necessary, and this is expressed in the AoP natural environment and taken care of by environmental LCA [69]. The interaction between human beings, expressed in the AoP human dignity and well-being are the topic for SLCA [70]. Human health is addressed as AoP in LCA and possibly also as AoP in SLCA. Natural resources is an AoP for LCA, but could also be AoP for LCA-type LCC (see for example [71] that extends natural resources with raw materials in the anthropogenic stocks). This shows that further development of the AoP for the different life cycle techniques is necessary.

Impact pathways [72], between the life cycle inventory (e.g., costs) and the AoP should be developed for LCA-type LCC and need to be coordinated with the further development of the AoP and impact pathways for LCA and SLCA to avoid overlap and double counting.

To further develop and apply the method of LCSA - as a combination of LCA, LCA-type LCC and SLCA - a clear distinction between those three life cycle techniques is to be preferred. This makes it easier to aggregate the results and prevent overlapping and double counting among the different life cycle techniques. This distinction could be realized with a strong focus on the flows involved, e.g., monetary flows for LCA-type LCC and bio-physical and chemicals flows for environmental LCA or on the object of protection, i.e., the natural environment for LCA, human beings for SLCA and the economy for LCA-type LCC. However, some authors argue that the latter, in such a perspective, is superfluous as the economic dimension should be rather integrated (and partly already is) in SLCA [73].

Another possibility is to address all three dimensions (environment, economy and society) in each life cycle technique. That means that LCA-type LCC address natural environment and human wellbeing in addition to economic wellbeing, and that LCA, in addition to natural environment, also has a kind of economic AoP, for example economic externalities. These topics need to be considered in the future development of the LCSA method.

\section{Acknowledgements}

We thank two anonymous reviewers for valuable comments as well as Barbra Ruben and the design team involving Kai Lindow, Robert Woll and Rainer Stark at Department of Industrial Information Technology, Technische Universitaet Berlin. This research is supported by the German Research Foundation DFG as part of a larger university wide research project "Methodische Nachhaltigkeitsbewertung von Maschinenkomponenten im Entwicklungsprozess".

\section{References and Notes}

1. World Commission on Environment and Development. Our Common Future; Oxford University Press: Oxford, UK, 1987; pp. XV, 400.

2. Environmental Management-Life Cycle Assessment-Principles and Framework (ISO 14040:2006), 2nd ed.; ISO: Geneva, Switzerland, 2006; p. 20. 
3. Environmental Management-Life Cycle Assessment-Requirements and Guidelines (ISO 14044:2006); ISO: Geneva, Switzerland, 2006; p. 46.

4. Finkbeiner, M.; Schau, E.M.; Lehmann, A.; Traverso, M. Towards life cycle sustainability assessment. Sustainability 2010, 2, 3309-3322.

5. Klöpffer, W.; Renner, I. Life-cycle based sustainability assessment of products. In Environmental Management Accounting for Cleaner Production; Schaltegger, S., Bennett, M., Burritt, R.L., Jasch, C., Eds.; Springer: Dordrecht, The Netherlands, 2009; Volume 24, pp. 91-102.

6. Klöpffer, W. Life-cycle based methods for sustainable product development. Int. J. Life Cycle Assess. 2003, 8, 157-159.

7. Hauschild, M.; Jeswiet, J.; Alting, L. From life cycle assessment to sustainable production: Status and perspectives. CIRP Ann. Manuf. Technol. 2005, 54, 1-21.

8. Environmental Management_Life Cycle Assessment_Principles and Framework (ISO 14040), 1st ed.; International Organization for Standardization: Geneve, Switzerland, 1997; p. 12.

9. Hunkeler, D.; Lichtenvort, K.; Rebitzer, G. Environmental Life Cycle Costing; CRC Press: Boca Raton, FL, USA, 2008.

10. Lichtenvort, K.; Rebitzer, G.; Huppes, G.; Ciroth, A.; Seuring, S.; Schmidt, W.-P.; Günther, E.; Hoppe, H.; Swarr, T.; Hunkeler, D. Introduction-History of life cycle costing, its categorization, and its basic framework. In Environmental Life Cycle Costing; Hunkeler, D., Lichtenvort, K., Rebitzer, G., Eds.; CRC Press: Boca Raton, FL, USA, 2008; pp. 1-6.

11. Rebitzer, G.; Nakamura, S. Environmental life cycle costing. In Environmental Life Cycle Costing; Hunkeler, D., Lichtenvort, K., Rebitzer, G., Eds.; CRC Press: Boca Raton, FL, USA, 2008; pp. 35-57.

12. Klöpffer, W. Outlook-Role of environmental life cycle costing in sustainability assessment. In Environmental Life Cycle Costing; CRC Press: Boca Raton, FL, USA, 2008.

13. Kelly, J.; Hunter, K. Life Cycle Costing of Sustainable Design; RICS Research: London, UK, 2009; p. 53.

14. Buildings and Constructed Assets-Service-Life Planning-Part 5: Life-Cycle Costing (ISO 15686-5); International Standardization Organization: Geneva, Switzerland, 2008.

15. Goldstein, B.; Eriksson, A.H. Livscykelkostnader-Till Vilken Nytta för Miljön och Plånboken? Nordiska ministerrådet: Köpenhamn, Denmark, 2010.

16. Bragança, L.; Mateus, R.; Koukkari, H. Building sustainability assessment. Sustainability 2010, 2 , 2010-2023.

17. Fiksel, J.; McDaniel, J.; Mendenhall, C. Sustainability: Ways of knowing/ways of acting. In Measuring Progress Towards Sustainability_Principles, Process, and Best Practices, Proceedings of the 8th International Network Conference of the Greening of Industry Network, GIN1999, Chapel Hill, NC, USA, 14-17 November 1999.

18. Utne, I.B. Life cycle cost (LCC) as a tool for improving sustainability in the Norwegian fishing fleet. J. Clean. Prod. 2009, 17, 335-344.

19. Meyer, R. Generatoren und Starter [Energieerzeugung und Bordnetz, Physikalische Grundlagen, Geräteausführungen für PKW und Nkw, Qualitätsmanagement, Werkstatt-Technik]; Bosch: Stuttgart, Germany, 2002; p. 104 S. 
20. Elektrische Energieversorgung. Automobilelektronik—Eine Einführung für Ingenieure; Reif, K., Ed.; Friedr. Vieweg \& Sohn: Wiesbaden, Germany, 2007; pp. 203-235.

21. Östlin, J.; Sundin, E.; Björkman, M. Product life-cycle implications for remanufacturing strategies. J. Clean. Prod. 2009, 17, 999-1009.

22. Teunter, R.H.; Flapper, S.D.P. Optimal core acquisition and remanufacturing policies under uncertain core quality fractions. Eur. J. Oper. Res. 2011, 210, 241-248.

23. Pokharel, S.; Liang, Y.J.; Lim, G.H. Pricing used products for remanufacturing. Eur. J. Oper. Res. 2009, 193, 390-395.

24. Niemann, J.; Schuh, G.; Baessler, E.; Eigner, M.; Stolz, M.; Steinhilper, R.; Janusz-Renault, G.; Hieber, M. Management des produktlebenslaufs. In Handbuch UnternehmensorganisationStrategien, Planung, Umsetzung; Bullinger, H.-J., Spath, D., Warnecke, H.-J., Westkämper, E., Eds.; Springer: Berlin, Germany, 2009; pp. 223-315.

25. Conserving Resources Through Remanufacturing, 2010. BOSCH Web site. Available online: http://csr.bosch.com/content/language2/html/6399_ENU_XHTML.aspx_ (accessed on 16 December 2010).

26. Kim, H.-J.; Skerlos, S.; Severengiz, S.; Seliger, G. Characteristics of the automotive remanufacturing enterprise with an economic and environmental evaluation of alternator products. Int. J. Sustain. Manuf. 2009, 1, 437-449.

27. Steinhilper, R.; Freiberger, S. Kfz-Ersatzteilversorgung durch Austauschteileproduktion (Remanufacturing) von mechatronischen Baugruppen spart Rohstoffe und Energie. Umweltwirtschaftsforum 2006, 14, 25-30.

28. Smith, V.M.; Keoleian, G.A. The value of remanufactured engines: Life-cycle environmental and economic perspectives. J. Ind. Ecol. 2004, 8, 193-221.

29. Pigosso, D.C.A.; Zanette, E.T.; Filho, A.G.; Ometto, A.R.; Rozenfeld, H. Ecodesign methods focused on remanufacturing. J. Clean. Prod. 2010, 18, 21-31.

30. Zwolinski, P.; Brissaud, D. Remanufacturing strategies to support product design and redesign. J. Eng. Des. 2008, 19, 321-335.

31. Warsen, J.; Laumer, M.; Momberg, W. Comparative life cycle assessment of remanufacturing and new manufacturing of a manual transmission. In Glocalized Solutions for Sustainability in Manufacturing; Hesselbach, J., Herrmann, C., Eds.; Springer: Berlin, Germany, 2011; pp. 67-72.

32. Ke, Q.; Zhang, H.-C.; Liu, G.; Li, B. Remanufacturing engineering literature overview and future research needs. In Glocalized Solutions for Sustainability in Manufacturing; Hesselbach, J., Herrmann, C., Eds.; Springer: Berlin, Germany, 2011; pp. 437-442.

33. Korpi, E.; Ala-Risku, T. Life cycle costing: A review of published case studies. Manag. Audit. J. 2008, 23, 240-261.

34. Dhillon, B.S. Life Cycle Costing-Techniques, Models, and Applications; Gordon and Breach Science Publishers: New York, NY, USA, 1989.

35. Bubeck, D. Life Cycle Costing (LCC) im Automobilbau-Analyse und Planung von Lebenszykluskosten bei der Entwicklung von Produkten und Produktsystemen; Verlag Dr. Kovač: Hamburg, Germany, 2002; p. 332.

36. Asiedu, Y.; Gu, P. Product life cycle cost analysis: State of the art review. Int. J. Prod. Res. 1998, 36, 883-908. 
37. Sachbilanz. Ökobilanz (LCA): Ein Leitfaden für Ausbildung und Beruf; Klöpffer, W., Grahl, B., Eds.; Wiley-VCH: Weinheim, Germany, 2009; pp. 63-194.

38. Fet, A.M.; Schau, E.M.; Haskins, C. A framework for environmental analyses of fish food production systems based on systems engineering principles. Syst. Eng. 2010, 13, 109-118.

39. Postawa, A.B.; Brandão, D.; Rubin, R.S.; Seliger, G. Sustainable product development and life cycle engineering. In Configuration of Value Creation Modules, Instantiated in Mini Factories for Disassembly of Printed Circuit Boards, Proceedings of the 7th Global Conference on Sustainable Manufacturing, Chennai, India, 2-4 December 2009.

40. Postawa, A.B.; Kleinsorge, M.; Krüger, J.; Seliger, G. Automated image based recognition of manual work steps in the remanufacturing of alternators. In Proceedings of the 8th Global Conference on Sustainable Manufacturing, Khalifa City, The United Arab Emirates, 22-24 November 2010.

41. Wikipedia Design for X, 2011. Wikipedia Web site. Available online: http://en.wikipedia.org/wiki/Design_for_X (accessed on 10 November 2011).

42. Matsumoto, M. Business frameworks for sustainable society: A case study on reuse industries in Japan. J. Clean. Prod. 2009, 17, 1547-1555.

43. Fügenschuh, A.; Gausemeier, P.; Seliger, G.; Severengiz, S. Scenario technique with integer programming for sustainability in manufacturing. In Proceedings of the 8th International Heinz Nixdorf Symposium-Changing Paradigms: Advanced Manufacturing and Sustainable Logistics, Paderborn, Germany, 21-22 April 2010; p. 12.

44. Höpfner, U.; Hanusch, J.; Lambrecht, U. Abwrackprämie und Umwelt-eine erste Bilanz; IFEU_-Institut für Energie-und Umweltforschung Heidelberg \& Bundesministerium für Umwelt, Naturschutz und Reaktorsicherheit (BMU): Berlin, Germany, 2009; p. 13.

45. Warburg, N.; Mailaender, E.; Herrmann, C.; Eyerer, P.; Reckziegel, C.; Saatkamp, T.; Stutz, M. Obtaining environmental benefits by application of electronic systems-Automotive LCA case study: Starter generator vs. conventional system. In Proceedings of the 2002 IEEE International Symposium on Electronics and the Environment, San Francisco, CA, USA, 6-9 May 2002; pp. 27-31.

46. Postawa, A.B. Department for Machine Tools and Factory Management, Technische Universitaet Berlin: Berlin, Germany. Personal communication about alternator parts and their replacement probability, 2010.

47. Bokranz, R.; Landau, K. Produktivitätsmanagement von Arbeitssystemen: MTM-Handbuch; Schäffer-Poeschel: Stuttgart, Germany, 2006.

48. Maynard, H.B.; Stegemerten, G.; Schwab, J. Methods-Time Measurement; McGraw-Hill: New York, NY, USA, 1948; p. 292.

49. Sincavage, J.R.; Haub, C.; Sharma, O. Labor costs in India's organized manufacturing sector. Mon. Labor Rev. 2010, 133, 3-22.

50. Statistics Sierra Leone. 2009 Annual Economic Survey; Statistics Sierra Leone, Economic Statistics Division: Freetown, Sierra Leone, December 2010; p. 32.

51. India's Organized Manufacturing Sector, 2011. U.S. Bureau of Labor Statistics Web site. Available online: http://www.bls.gov/fls/india.htm (accessed on 3 August 2011). 
52. International comparisons of hourly compensation costs in manufacturing, 2008. U.S. Bureau of Labor Statistics Web site. Available online: http://www.bls.gov/news.release/pdf/ichcc.pdf (accessed on 17 December 2010).

53. Global Wages Database, 2010. International Labour Organization Web site. Available online: http://www.ilo.org/legacy/english/protection/travail/pdf/wagedatabase10.xls (accessed on 4 August 2011).

54. Annual Survey of Industries, 2011. The Ministry of Statistics and Programme Implementation Web site. Available online: http://mospi.nic.in/stat_act_t3.htm (accessed on 4 August 2011).

55. Preisauszug der Niederlassung Berlin [Price list for the Berlin branch]; Kia Motors Deutschland GmbH: Berlin, Germany, 26 May 2009.

56. Lichtmaschine KIA Retona [Alternator KIA Retona], 2009. TeileHaber Web site. Available online: http://www.teilehaber.de/hellalichtmaschine.-generator-kia-retona.-sportage-id2100553. html (accessed on 29 July 2009).

57. The World Bank Trading Across Borders_-Data, 2010. Doing Business Web site. Available online: http://www.doingbusiness.org/data/exploretopics/trading-across-borders\# (accessed on 8 August 2011).

58. Djankov, S.; Freund, C.; Pham, C.S. Trading on time. Rev. Econ. Stat. 2010, 92, 166-173.

59. Global Shipping Costs Home Page. Available online: http://www.globalshippingcosts.com/ (accessed on 8 August 2011).

60. Koffler, C.; Rohde-Brandenburger, K. On the calculation of fuel savings through lightweight design in automotive life cycle assessments. Int. J. Life Cycle Assess. 2010, 15, 128-135.

61. Heinzel, A.; Mathiak, J.; Dokupil, M.; Roes, J. Problemstellung, chancen und risiken von brennstoffzellen APU'ss. In Proceedings of OTTI-Profiforum "Brennstoffzellen-Entwickler und Anwender Berichten”, Berlin, Germany, 7-8 October 2003.

62. Bradfield, M. Improving Alternator Efficiency Measurably Reduces Fuel Costs; Remy Inc.: Pendleton, IN, USA, 2008.

63. Pricelist Total Petrol Station, Berlin, Germany, 24 June 2010.

64. Huppes, G.; Ciroth, A.; Lichtenvort, K.; Rebitzer, G.; Schmidt, W.-P.; Seuring, S. Modeling for life cycle costing. In Environmental Life Cycle Costing; Hunkeler, D., Lichtenvort, K., Rebitzer, G., Eds.; CRC Press: Boca Raton, FL, USA, 2008; pp. 17-34.

65. Sundin, E.; Björkman, M.; Jacobsson, N. Electronics and the environment. In Analysis of Service Selling and Design for Remanufacturing, Proceedings of the 2000 IEEE International Symposium on Electronics and the Environment, ISEE 2000, San Francisco, CA, USA, 8-10 May 2000; pp. 272-277.

66. ILO Wages in manufacturing (Table 5B), 2010. International Labour Organization Web site. Available online: http://laborsta.ilo.org/ (accessed on 17 December 2010).

67. Ijomah, W.L.; McMahon, C.A.; Hammond, G.P.; Newman, S.T. Development of design for remanufacturing guidelines to support sustainable manufacturing. Robot. Comput-Integr. Manuf. 2007, 23, 712-719.

68. Costanza, R.; Daly, H.E. Natural capital and sustainable development. Conserv. Biol. 1992, 6, $37-46$. 
69. Udo de Haes, H.; Jolliet, O.; Finnveden, G.; Hauschild, M.; Krewitt, W.; Müller-Wenk, R. Best available practice regarding impact categories and category indicators in life cycle impact assessment-Part I. Int. J. Life Cycle Assess. 1999, 4, 66-74.

70. Dreyer, L.; Hauschild, M.; Schierbeck, J. A Framework for social life cycle impact assessment. Int. J. Life Cycle Assess. 2006, 11, 88-97.

71. Schneider, L.; Berger, M.; Finkbeiner, M. The anthropogenic stock extended abiotic depletion potential (AADP) as a new parameterisation to model the depletion of abiotic resources. Int. J. Life Cycle Assess. 2011, 16, 929-936.

72. Krewitt, W.; Mayerhofer, P.; Trukenmüller, A.; Friedrich, R. Application of the impact pathway analysis in the context of LCA. Int. J. Life Cycle Assess. 1998, 3, 86-94.

73. Jørgensen, A.; Hermann, I.; Mortensen, J. Is LCC relevant in a sustainability assessment? Int. J. Life Cycle Assess. 2010, 15, 531-532.

(C) 2011 by the authors; licensee MDPI, Basel, Switzerland. This article is an open access article distributed under the terms and conditions of the Creative Commons Attribution license (http://creativecommons.org/licenses/by/3.0/). 